\title{
The association between vitamin $D$ receptor gene polymorphisms (Taql and Fokl), Type 2 diabetes, and micro-/macrovascular complications in postmenopausal women
}

\author{
This article was published in the following Dove Press journal: \\ The Application of Clinical Genetics \\ I August 2016 \\ Number of times this article has been viewed
}

Juliana Maia'

Andreia Soares da Silva ${ }^{2}$

Rodrigo Feliciano do

Carmo $^{3}$

Taciana Furtado de

Mendonça ${ }^{2}$

Luiz Henrique Maciel Griz

Patricia Moura ${ }^{2}$

Francisco Bandeira'

'Division of Endocrinology and Diabetes, Agamenon Magalhães

Hospital, ${ }^{2}$ Institute of Biological

Sciences, University of Pernambuco

Medical School, Recife, ${ }^{3}$ Federal

University of São Francisco Valley,

Petrolina, Pernambuco, Brazil
Correspondence: Juliana Maia

Division of Endocrinology and Diabetes, Agamenon Magalhães Hospital, University of Pernambuco Medical School, Rua Marechal Rondon, 120, ap 1602, Recife, Pernambuco 5206I-050, Brazil Email maia.juliana@gmail.com
Introduction: Since there is evidence of the action of vitamin D as a modulator of insulin release and atherosclerosis, it may well be that the vitamin D receptor polymorphisms are associated with diabetes and its chronic complications.

Aims: To examine the associations between vitamin D receptor polymorphisms (FokI and TaqI) and Type 2 diabetes (T2DM) and its associated chronic complications in postmenopausal women. Methods: This cross-sectional study analyzed 100 postmenopausal women with T2DM (mean age $65.7 \pm 7.18$ years) and 100 postmenopausal women without diabetes in the control group (mean age $65.1 \pm 9.18$ years; $P=0.1608$ ). We evaluated clinical and metabolic parameters and analyzed TaqI and FokI polymorphisms.

Results: There were no significant differences in genotype and allele frequencies between patients and controls in either of the polymorphisms studied. In the group of patients with diabetes, there were no significant differences in either polymorphism in relation to stroke, retinopathy, nephropathy, or neuropathy. However, in patients with T2DM and coronary artery disease, $f$ genotype $(P=0.0361)$ and the combination of $\mathrm{Ff}+\mathrm{ff}$ genotypes were observed less frequently $(P=0.0462)$.

Conclusion: This study suggests the potential protective factor of FokI polymorphism for coronary artery disease in postmenopausal women with T2DM in the recessive model.

Keywords: Type 2 diabetes, VDR, polymorphism, vitamin D

\section{Introduction}

Although vitamin D is recognized mainly for its effects on bone metabolism, it is also known that it regulates multiple aspects of cellular differentiation and replication in many target tissues, including endocrine pancreas. ${ }^{1,2}$ Some studies have suggested that vitamin D plays an important role in the mechanism of insulin release and in the maintenance of glucose tolerance and have also shown the association between vitamin $\mathrm{D}$ deficiency and Type 2 diabetes (T2DM). ${ }^{3,4}$

Cardiovascular disease (CVD) is the leading cause of mortality and morbidity in patients with diabetes and the largest contributor to the cost of diabetes. ${ }^{5}$ Various studies have also suggested the association between reduced 25-hydroxyvitamin D (25OHD) concentrations and an increased risk of atherosclerosis, endothelial dysfunction, and coronary artery disease (CAD).$^{6-9}$ 
Recent developments have led public health authorities to take an increasing interest in vitamin D research, since vitamin $\mathrm{D}$ deficiency is highly prevalent in the general population, ${ }^{10}$ even in those living in areas with abundant sunlight. ${ }^{11,12}$

It is well known that metabolic actions related to vitamin $\mathrm{D}$, on target cells, are mediated by the binding of 1,25-dihydroxyvitamin D to its specific cytosolic/nuclear receptor, which has been identified in many tissues. ${ }^{13}$ The vitamin $\mathrm{D}$ receptor (VDR) is a member of the steroid/thyroid hormone receptor family and functions as a transcriptional activator of many genes. ${ }^{14}$ The VDR gene is located on chromosome 12q13.11 in humans and consists of eleven exons. ${ }^{15}$ Several polymorphisms of the VDR gene have been identified, but four single-nucleotide polymorphisms (SNPs) of this gene are the ones that have been most studied, namely, BsmI (rs1544410), ApaI (rs7975232), TaqI (T>C; rs731236), and FokI (C>T; rs2228570, formerly known as rs10735810).

The FokI polymorphism occurs in the start codon of VDR and its polymorphic form (f) leads to the translation of a longer VDR protein variant (427 amino acid), and some in vitro studies suggest that it functions less effectively than the shorter VDR protein (424 amino acid) encoded by the F allele. ${ }^{15-17}$ The functional activity of this SNP is yet to be fully understood, since other in vitro experiments have failed to show this difference. ${ }^{18}$ TaqI polymorphism results from a mutation in a transcriber region located in exon 9 of the VDR gene. However, there are no studies demonstrating its functionality. ${ }^{15}$

Several studies in recent years have attempted to elucidate the possible relationship between polymorphisms of the VDR gene and diabetes and CVD, but the results are still controversial and substantial differences have been observed between SNPs and the ethnic groups analyzed. ${ }^{19-26}$ This further emphasizes the need to conduct studies to analyze VDR polymorphisms in different ethnic populations.

The aims of this study were, therefore, to access the genotypic distribution of FokI and TaqI polymorphisms of VDR in a population of postmenopausal women with T2DM and in a control group, and to evaluate whether these two SNPs of VDR (FokI and TaqI) are associated with micro- and macrovascular complications.

\section{Methods}

\section{Study design}

This cross-sectional study was carried out between September 2013 and August 2014 in the city of Recife (Brazil) and comprised 100 female patients with physiological menopause and diagnosis of T2DM, according to the American Diabetes Association criteria. ${ }^{5} \mathrm{~A}$ total of 100 postmenopausal women without diabetes were enrolled as the control group. The subjects of the study were recruited from the community. The study was approved by the Ethics in Research Committee of Agamenon Magalhães Hospital (CEP-HAM, Recife, Brazil). All patients gave their written informed consent to take part in this study.

The exclusion criteria were as follows: patients with Type 1 diabetes; end-stage renal disease; use of glucocorticoids; use of vitamin D replacement therapy; use of hormone replacement therapy; primary hyperparathyroidism; Paget's disease of bone; malabsorption syndrome; and/or active neoplasia.

The patients were interviewed by a physician, answered a standard questionnaire, and underwent a complete physical examination, including measurement of height, weight, waist circumference, and blood pressure. Skin phototypes were classified in six types, according to Fitzpatrick's classification (Type 1 as the lightest and Type 6 as the darkest). ${ }^{27}$ Blood samples were obtained from all participants, after overnight fasting. Low-density lipoprotein cholesterol, high-density lipoprotein cholesterol, triglyceride levels, fasting blood glucose, and glycated hemoglobin (HbAlc) were evaluated. Biochemical tests were processed in a dry chemistry autoanalyzer (Vitro System, Johnson \& Johnson, New Brunswick, $\mathrm{NJ}, \mathrm{USA}$ ) and HbAlc concentrations were determined by immunoturbidimetric assay (Cobas 501, Roche Diagnostic, Rotkreuz, Switzerland).

Serum 25OHD levels were measured by electrochemiluminescent competitive immunoassay (Diasorin-Liaison, Saluggia, Italy), with the interassay and intra-assay coefficients of variation of $8 \%-15 \%$ and $8 \%-13 \%$, respectively, with a minimum limit of detection of $2 \mathrm{ng} / \mathrm{mL} .^{28}$

\section{DNA extraction and genotyping}

The DNA was extracted from whole blood samples (ethylenediaminetetraacetic acid) using the QIAamp Mini Spin Columns kit (QIAGEN, Venlo, the Netherlands) in accordance with the manufacturer's instructions. For detection of polymorphic variable, the real-time polymerase chain reaction method in the TAQMAN ${ }^{\circledR}$ (Thermo Fisher Scientific, Waltham, MA, USA) system was used.

We genotyped the following SNP of the VDR gene: FokI (rs10735810/ID: C_12060045_20) and TaqI (rs731236/ ID:C__2404008_10) according to the manufacturer's instructions (http://www.thermofisher.com/order/genomedatabase). FokI polymorphism results in different translation 
initiation sites due to the replacement of cytosine (C) by thymine (T) and TaqI polymorphism is constituted by the silent replacement of thymine (T) by cytosine (C).

\section{Statistical evaluation}

Data for categorical variables are presented as numbers (percentages), and data for continuous variables are presented as mean values (standard deviations). The differences in genotype and allele frequencies were analyzed by Pearson's chi-square test and Fisher's exact test. Differences were considered statistically significant for $P$-values of less than 0.05 . Odds ratio (OR) with a $95 \%$ confidence interval (CI) was determined to estimate the association between variables. The GraphPad Prism program (version 6.0) for Windows (GraphPad Software, San Diego, CA, USA) was used for the analysis. To determine the Hardy-Weinberg equilibrium in the population, the ARLEQUIN program was used (version 3.11, Bern, Swiss).

\section{Results}

The clinical characteristics of the patients and control group are summarized in Table 1. Age distribution between T2DM patients (65.7 \pm 7.18 years) and controls (65.1 \pm 9.18 years) was not significantly different $(P=0.1608)$. The frequency of hypertension and body mass index $>25 \mathrm{~kg} / \mathrm{m}^{2}$ were higher in the T2DM patients than in the controls $(P=0.0001$ and $P=0.0355$, respectively). Mean waist circumference, serum triglyceride levels, and $\mathrm{HbA} 1 \mathrm{c}$ were elevated in patients compared with controls. There were no significant differences in skin phototype between patients and controls. Serum 25OHD levels below $30 \mathrm{ng} / \mathrm{mL}$ were found to be significantly more prevalent in T2DM patients than in the control group (74\% and $48 \%$, respectively; $P=0.0001)$. Using cutoffs for serum 25OHD levels below $20 \mathrm{ng} / \mathrm{mL}$, the prevalence of vitamin $\mathrm{D}$ deficiency was $12 \%$ in patients with diabetes and $7 \%$ in the control group $(P=0.3350)$.

There were no significant differences in genotype and allele frequency distribution between T2DM patients and controls in either the TaqI or FokI analysis (Tables 2 and 3). The prevalence of TaqI genotypes was 45\% TT, 46\% Tt, 9\% $\mathrm{tt}$ in $\mathrm{T} 2 \mathrm{DM}$ patients, and $49 \% \mathrm{TT}, 39 \% \mathrm{Tt}$, and $12 \% \mathrm{tt}$ in the control group (Table 2). The frequency of the $\mathrm{T}$ allele in T2DM patients was $68 \%$ and that of the t allele $32 \%$, while in the control group, it was $68.5 \%$ and $31.5 \%$, respectively ( $P=1.0000$; Table 2). The prevalence of FokI was $46 \% \mathrm{FF}$, $42 \% \mathrm{Ff}$, and $12 \% \mathrm{ff}$ in $\mathrm{T} 2 \mathrm{DM}$ patients and $38 \% \mathrm{FF}, 47 \% \mathrm{Ff}$, and $15 \% \mathrm{ff}$ in the control group. The frequency of the $\mathrm{F}$ allele in T2DM patients was $67 \%$ and that of the fallele $33 \%$, while
Table I Characteristics of study participants

\begin{tabular}{|c|c|c|c|}
\hline \multirow[t]{2}{*}{ Characteristics } & \multirow{2}{*}{$\begin{array}{l}\text { Cases } \\
(n=100)\end{array}$} & \multirow{2}{*}{$\begin{array}{l}\text { Control } \\
(n=100)\end{array}$} & \multirow[t]{2}{*}{$P$-value } \\
\hline & & & \\
\hline \multicolumn{4}{|l|}{ Age } \\
\hline Mean $( \pm S D)$ & $65.7( \pm 7.18)$ & $65.1( \pm 9.18)$ & $P a=0.16$ \\
\hline \multicolumn{4}{|l|}{ Hypertension (n) } \\
\hline Yes & 86 & 60 & \\
\hline No & 14 & 40 & $P^{b}=0.000 I^{*}$ \\
\hline \multicolumn{4}{|l|}{ BMI $\left(k g / m^{2}\right)(n)$} \\
\hline Normal $(<25)$ & 19 & 33 & \\
\hline Overweight/obese (>25) & 81 & 67 & $P^{b}=0.0355^{*}$ \\
\hline \multicolumn{4}{|l|}{$W C(\mathrm{~cm})$} \\
\hline Mean $( \pm S D)$ & $99( \pm 12)$ & $89( \pm \mid 4)$ & $P^{a}<0.000$ I* \\
\hline \multicolumn{4}{|l|}{ HbAlc (\%) } \\
\hline Mean $( \pm S D)$ & $7.8( \pm 1.7)$ & $5.5( \pm 0.3)$ & $\mathrm{P}^{\mathrm{a}}<0.000$ I $^{*}$ \\
\hline \multicolumn{4}{|l|}{ Triglycerides (mg/dL) } \\
\hline Mean $( \pm S D)$ & $160( \pm 68)$ & $135( \pm 62)$ & $P a=0.0200 *$ \\
\hline \multicolumn{4}{|l|}{ Skin phototype(n) } \\
\hline$I+I I$ & 6 & 3 & \\
\hline III + IV & 70 & 58 & $P^{b}=0.73$ \\
\hline$V+\mathrm{VI}$ & 24 & 39 & $P^{b}=0.15$ \\
\hline \multicolumn{4}{|l|}{$25 \mathrm{OHD}(\mathrm{ng} / \mathrm{mL})(\mathrm{n})$} \\
\hline $\begin{array}{l}\text { Deficiency/insufficiency } \\
(<30 \mathrm{ng} / \mathrm{mL})\end{array}$ & 74 & 48 & \\
\hline Normal (>30 ng/mL) & 26 & 52 & $P^{b}=0.0001 *$ \\
\hline
\end{tabular}

Notes: *Statistically significant difference $(P<0.05)$; 'Student's $t$-test; ${ }^{b}$ Fisher's exact test. Abbreviations: SD, standard deviation; BMI, body mass index; WC, waist circumference; HbAlc, glycated hemoglobin; 25OHD, 25-hydroxyvitamin D.

Table 2 Distribution of VDR (Taql) polymorphism genotypes and allele frequencies between T2DM patients and control groups

\begin{tabular}{llllll}
\hline VDR & $\begin{array}{l}\text { T2DM patients } \\
\mathbf{n}=100\end{array}$ & $\begin{array}{l}\text { Control } \\
\mathbf{n}=100\end{array}$ & $\begin{array}{l}P_{\text {-value }} \\
\text { O OR }\end{array}$ & 95\% Cl \\
\hline Genotype & & & & & \\
AA (TT) & $45(45 \%)$ & $49(49 \%)$ & - & & \\
AG (Tt) & $46(46 \%)$ & $39(39 \%)$ & 0.45 & 1.28 & $0.68-2.4 I$ \\
GG (tt) & $9(9 \%)$ & $12(12 \%)$ & 0.81 & 0.82 & $0.28-2.33$ \\
AG + GG & $55(55 \%)$ & $52(52 \%)$ & 0.67 & 1.17 & $0.65-2.13$ \\
$(T t+t t)$ & & & & & \\
Alleles & & & & & \\
A (T) & $136(68 \%)$ & $137(68.5 \%)-$ & & \\
G (t) & $64(32 \%)$ & $63(31.5 \%)$ & 1.00 & 1.02 & $0.66-1.59$ \\
\hline
\end{tabular}

Notes: "Chi-square test. “-” indicates no data.

Abbreviations: VDR, vitamin D receptor; T2DM, Type 2 diabetes; OR, odds ratio; $\mathrm{Cl}$, confidence interval.

in the control group, it was $61.5 \%$ and $38.5 \%$, respectively ( $P=0.1256)$. The study subjects were in Hardy-Weinberg equilibrium for both TaqI and FokI.

In addition, we also compared the VDR (TaqI and FokI) genotypes and allele frequencies with the presence of macro- and microvascular complications of diabetes. There were no significant differences in relation to stroke, retinopathy, nephropathy, or neuropathy. No statistically significant differences were found in the TaqI genotype or allele frequency in the groups of patients with diabetes 
Table 3 Distribution of VDR (Fokl) polymorphism genotypes and allele frequencies between T2DM patients and control groups

\begin{tabular}{|c|c|c|c|c|c|}
\hline VDR & $\begin{array}{l}\text { T2DM patients } \\
n=100\end{array}$ & $\begin{array}{l}\text { Control } \\
n=100\end{array}$ & $P$-value ${ }^{a}$ & OR & $95 \% \mathrm{Cl}$ \\
\hline \multicolumn{6}{|l|}{ Genotype } \\
\hline GG (FF) & 46 (46\%) & 38 (38\%) & - & & \\
\hline$A G(F f)$ & 42 (42\%) & 47 (47\%) & 0.13 & 1.4 & $0.77-2.56$ \\
\hline $\mathrm{AA}$ (ff) & $12(12 \%)$ & 15 (I5\%) & 0.17 & 1.5 & $0.63-3.62$ \\
\hline$A G+G G$ & 54 (54\%) & 62 (62\%) & 0.13 & 1.39 & $0.79-2.4$ \\
\hline \multicolumn{6}{|l|}{$(F f+f f)$} \\
\hline \multicolumn{6}{|l|}{ Alleles } \\
\hline$G(F)$ & 134 (67\%) & $123(61.5 \%)$ & - & & \\
\hline$A(f)$ & 66 (33\%) & 77 (38.5\%) & 0.13 & 1.2 & $0.84-1.91$ \\
\hline
\end{tabular}

Notes: aChi-square test. “-” indicates no data.

Abbreviations: VDR, vitamin $\mathrm{D}$ receptor; T2DM, Type 2 diabetes; OR, odds ratio; $\mathrm{Cl}$, confidence interval.

and without a history of CAD (Table 4), but in the FokI analysis (Table 5), compared with genotype FF, genotype Ff was likely to be a protective factor for CAD (FF vs Ff, $P=0.0391$, OR $0.29,95 \%$ CI $0.09-1.01)$. We also found a significant association between FokI polymorphism and $\mathrm{CAD}$ in the recessive model ( $\mathrm{FF}$ vs $\mathrm{Ff}+\mathrm{ff}, P=0.0462$, OR $0.35,95 \%$ CI $0.12-1.02$ ).

\section{Discussion}

In our study, no significant differences were found in genotype and allele frequency distribution of VDR (TaqI and FokI) genes between postmenopausal Brazilian women with T2DM and those of the control group. However, in T2DM patients with a history of CAD, we observed a lower frequency of the Ff genotype $(P=0.0361)$ and the combination of genotypes $\mathrm{Ff}+\mathrm{ff}(P=0.0462)$.

The prevalence of VDR TaqI and FokI polymorphism genotypes was similar to data reported previously in another study that also analyzed Brazilian postmenopausal women. ${ }^{29}$

Reports on the association between VDR gene polymorphisms and T2DM have been inconsistent. Our analysis did not find any evidence of an association between TaqI and FokI polymorphism and T2DM among Brazilian postmenopausal women. Two meta-analyses showed data similar to ours regarding the lack of evidence of any association of the TaqI polymorphism with T2DM..$^{30,31}$ However, with regard to the FokI polymorphism, these meta-analyses found some statistical evidence that the f allele may be a susceptibility allele for T2DM in an Asian population. ${ }^{30,31}$ It is important to emphasize that this result may vary according to the study population because of substantial differences in VDR polymorphisms between races, which have already been demonstrated. ${ }^{15}$ In fact, a study in Polish Caucasians found a result similar to ours, with no evidence for an association of FokI polymorphism with T2DM. ${ }^{22}$
Table 4 Distribution of VDR (Taql) polymorphism genotypes and allele frequencies in T2DM patients according to the presence of CAD

\begin{tabular}{llll}
\hline CAD & & & \\
\hline VDR & $\begin{array}{l}\text { Yes } \\
\mathbf{n = 1 8}\end{array}$ & $\begin{array}{l}\text { No } \\
\mathbf{n = 8 2}\end{array}$ & P-value $^{\mathbf{a}}$ \\
\hline Genotype & & & \\
AA (TT) & $8(44 \%)$ & $37(45 \%)$ & \\
AG (Tt) & $7(39 \%)$ & $39(48 \%)$ & 0.78 \\
GG (tt) & $3(17 \%)$ & $6(7 \%)$ & 0.37 \\
AG + GG (Tt + tt) & $10(56 \%)$ & $45(55 \%)$ & 1.00 \\
Alleles n (\%) & & & \\
A (T) & $23(64 \%)$ & $113(69 \%)$ & \\
G (t) & $13(36 \%)$ & $51(31 \%)$ & 0.56 \\
\hline Note:Chisqas
\end{tabular}

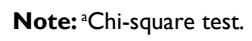

Abbreviations: VDR, vitamin $D$ receptor; T2DM, Type 2 diabetes; CAD, coronary artery disease.

Table 5 Distribution of VDR (Fokl) polymorphism genotypes and allele frequencies in T2DM patients according to the presence of CAD

\begin{tabular}{llllll}
\hline CAD & & & & & \\
\hline VDR & $\begin{array}{l}\text { Yes } \\
\mathbf{n = 1 8}\end{array}$ & $\begin{array}{l}\text { No } \\
\mathbf{n = 8 2}\end{array}$ & -value $^{\mathrm{a}}$ & OR & $\mathbf{9 5 \%} \mathbf{C l}$ \\
\hline Genotype & & & & & \\
GG (FF) & $12(67 \%)$ & $34(42 \%)$ & - & & \\
AG (Ff) & $4(22 \%)$ & $38(46 \%)$ & $0.036 I^{*}$ & 0.29 & $0.09-1.01$ \\
AA (ff) & $2(11 \%)$ & $10(12 \%)$ & 0.39 & 0.57 & $0.11-2.96$ \\
AG + AA & $6(33 \%)$ & $48(58 \%)$ & $0.0462^{*}$ & 0.35 & $0.12-1.02$ \\
(Ff + ff) & & & & & \\
Alleles n (\%) & & & & & \\
G (F) & $28(78 \%)$ & $106(65 \%)$ & - & & \\
A (f) & $8(22 \%)$ & $58(35 \%)$ & 0.09 & 0.52 & $0.22-1.22$ \\
\hline
\end{tabular}

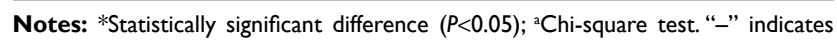
no data.

Abbreviations: VDR, vitamin $D$ receptor; T2DM, Type 2 diabetes; OR, odds ratio; $\mathrm{Cl}$, confidence interval; CAD, coronary artery disease.

We likewise found no association between TaqI polymorphism and CAD among postmenopausal Brazilian women with T2DM. A prospective study found a significant association between the $t$ allele of TaqI VDR and baseline cases of CAD in a French population. ${ }^{24}$ On the other hand, in a study of the Egyptian population, the TaqI showed no significant association with CAD. ${ }^{32}$ As it has been suggested that the TaqI polymorphism is a silent mutation, it results in no amino acid sequence change. ${ }^{15}$ This evidence may partly explain the result of this study.

The analysis of FokI SNPs of VDR, in our study, showed that the Ff genotype is probably a protective factor for CAD in postmenopausal women with T2DM; moreover, when we compared a recessive model for analysis $(\mathrm{Ff}+\mathrm{ff})$, there was a significant association with CAD.

Accumulating evidence suggests that low serum levels of vitamin D are associated with an increased risk of 
atherosclerosis, endothelial dysfunction, and CVD. ${ }^{6,7,33,34}$ The epigenetic effects of vitamin D include modulation of smooth muscle cell proliferation, vascular calcification, inflammation, and thrombosis. ${ }^{35-37}$ In addition, vitamin D is a negative regulator of renin-angiotensin. ${ }^{38-40}$ VDR polymorphism is thus a potential candidate for coronary atherosclerosis.

Ortlepp et $\mathrm{al}^{20}$ reported no association between BsmI polymorphism of VDR and coronary angiographic phenotypes in a large study population. A cohort from a multinational prospective study found that the haplotype comprising the minor allele of $B s m I$, the major allele of $A p a I$, and the minor allele of TaqI of VDR was associated with an increased risk of CAD in T2DM patients. ${ }^{24}$ Our study did not evaluate the ApaI and BsmI polymorphisms; it did, however, analyze the FokI SNP, which is considered to be an independent marker of the VDR gene because it is not in linkage disequilibrium with other VDR SNPs, and there is speculation on its possible relationship with the functionality of the VDR protein. ${ }^{15}$

With regard to the association of genotype and allele frequencies of the FokI polymorphism with CAD, a Chinese study observed no significant evidence..$^{41}$ Another study in a Caucasian population found no significant differences in anthropometric and biochemical features of CVD between genotypes of FokI in female and male groups, ${ }^{42}$ but it is difficult to compare those findings with ours because of differences in the study population. Both studies analyzed men and women in general, while our population is specific to postmenopausal women with T2DM.

Our findings cannot be related to the VDR functionality of FokI SNP, since the studies on functional differences in the VDR protein encoded by the polymorphic form are conflicting, suggesting the need for further studies on this topic.

Vaidya et $\mathrm{al}^{43}$ observed that both higher serum 25OHD levels and the fallele at FokI were independently associated with lower plasma renin activity in a large population of hypertensives..$^{43}$ As plasma renin activity is associated with CVD, this finding is consistent with our finding of an association between the recessive model of FokI $(\mathrm{Ff}+\mathrm{ff})$ and CAD.

Our data therefore suggest that the association observed between the recessive model of FokI polymorphism and CAD in postmenopausal women with T2DM as a protective factor may be mediated by modulation of the renin-angiotensin system. However, additional studies with a larger sample size across various ethnic groups are needed to fully determine such an association and clarify the mechanism involved.

Some potential limitations should be considered in this study, such as the small size of the study population, the cross-sectional design of the study, and the fact that patients did not undergo diagnostic angiography, and so there is a possibility that patients with asymptomatic CAD were overlooked.

\section{Conclusion}

Our study suggests that the FokI polymorphism in the VDR gene is a protective factor for CAD in postmenopausal women with T2DM in the recessive model. Our data evidenced no association between the polymorphisms analyzed (FokI and TaqI) and T2DM and other chronic complications of diabetes.

\section{Disclosure}

The authors report no conflicts of interests in this work.

\section{References}

1. Walters MR. Newly identified actions of the vitamin D endocrine system. Endocr Rev. 1992;13(4):719-764.

2. Lee S, Clark SA, Gill RK, Christakos S. 1,25-Dihydroxyvitamin D3 and pancreatic beta-cell function: vitamin D receptors, gene expression, and insulin secretion. Endocrinology. 1994;134(4):1602-1610.

3. Mattila C, Knekt P, Männistö S, et al. Serum 25-hydroxyvitamin D concentration and subsequent risk of type 2 diabetes. Diabetes Care. 2007;30(10):2569-2570.

4. Song Y, Wang L, Pittas AG, et al. Blood 25-hydroxy vitamin D levels and incident type 2 diabetes: a meta-analysis of prospective studies. Diabetes Care. 2013;36(5):1422-1428.

5. American Diabetes Association. Standards of medical care in diabetes - 2014. Diabetes Care. 2014;37 (Suppl 1):S14-S80.

6. Brewer LC, Michos ED, Reis JP. Vitamin D in atherosclerosis, vascular disease, and endothelial function. Curr Drug Targets. 2011;12(1):54-60.

7. Grandi NC, Breitling LP, Brenner H. Vitamin D and cardiovascular disease: systematic review and meta-analysis of prospective studies. Prev Med. 2010;51(3-4):228-233.

8. Kim DH, Sabour S, Sagar UN, Adams S, Whellan DJ. Prevalence of hypovitaminosis D in cardiovascular diseases (from the National Health and Nutrition Examination Survey 2001 to 2004). Am J Cardiol. 2008;102(11):1540-1544.

9. Wang TJ, Pencina MJ, Booth SL, et al. Vitamin D deficiency and risk of cardiovascular disease. Circulation. 2008;117(4):503-511.

10. Mithal A, Wahl DA, Bonjour JP, et al. Global vitamin D status and determinants of hypovitaminosis D. Osteoporos Int. 2009;20(11):1807-1820.

11. Bandeira F, Griz L, Freese E, et al. Vitamin D deficiency and its relationship with bone mineral density among postmenopausal women living in the tropics. Arq Bras Endocrinol Metabol. 2010;54(2):227-232.

12. Cabral MA, Borges CN, Maia JM, Aires CA, Bandeira F. Prevalence of vitamin D deficiency during the summer and its relationship with sun exposure and skin phototype in elderly men living in the tropics. Clin Interv Aging. 2013;8:1347-1351.

13. Bouillon R, Carmeliet G, Verlinden L, et al. Vitamin D and human health: lessons from vitamin D receptor null mice. Endocr Rev. 2008;29(6):726-776.

14. Mangelsdorf DJ, Thummel C, Beato $\mathrm{M}$, et al. The nuclear receptor superfamily: the second decade. Cell. 1995;83(6):835-839.

15. Uitterlinden AG, Fang Y, Van Meurs JB, Pols HA, Van Leeuwen JP. Genetics and biology of vitamin D receptor polymorphisms. Gene. 2004;338(2):143-156.

16. Arai H, Miyamoto K, Taketani Y, et al. A vitamin D receptor gene polymorphism in the translation initiation codon: effect on protein activity and relation to bone mineral density in Japanese women. J Bone Miner Res. 1997;12(6):915-921. 
17. Nejentsev S, Godfrey L, Snook H, et al. Comparative high-resolution analysis of linkage disequilibrium and tag single nucleotide polymorphisms between populations in the vitamin D receptor gene. Hum Mol Genet. 2004;13(15):1633-1639.

18. Gross C, Krishnan AV, Malloy PJ, Eccleshall TR, Zhao XY, Feldman D. The vitamin D receptor gene start codon polymorphism: a functional analysis of FokI variants. J Bone Miner Res. 1998;13(11): 1691-1699.

19. Bid HK, Konwar R, Aggarwal CG, et al. Vitamin D receptor (FokI, BsmI and TaqI) gene polymorphisms and type 2 diabetes mellitus: a North Indian study. Indian J Med Sci. 2009;63(5):187-194.

20. Ortlepp JR, Lauscher J, Hoffmann R, Hanrath P, Joost HG. The VDR gene variant is associated with the prevalence of Type 2 diabetes mellitus and coronary artery disease. Diabet Med. 2001;18:842-845.

21. Dilmec F, Uzer E, Akkafa F, Kose E, van Kuilenburg AB. Detection of VDR gene ApaI and TaqI polymorphisms in patients with type 2 diabetes mellitus using PCR-RFLP method in a Turkish population. J Diabetes Complications. 2010;24(3):186-191.

22. Malecki MT, Frey J, Moczulski D, Klupa T, Kozek E, Sieradzki J. Vitamin D receptor gene polymorphisms and association with type 2 diabetes mellitus in a Polish population. Exp Clin Endocrinol Diabetes. 2003;111(8):505-509.

23. Ortlepp JR, von Korff A, Hanrath P, Zerres K, Hoffmann R. Vitamin D receptor gene polymorphism $\mathrm{BsmI}$ is not associated with the prevalence and severity of CAD in a large-scale angiographic cohort of 3441 patients. Eur J Clin Invest. 2003;33(2):106-109.

24. Ferrarezi DA, Bellili-Muñoz N, Dubois-Laforgue D, et al. Allelic variations of the vitamin $\mathrm{D}$ receptor (VDR) gene are associated with increased risk of coronary artery disease in type 2 diabetics: the DIABHYCAR prospective study. Diabetes Metab. 2013;39(3):263-270.

25. Jia J, Ding H, Yang K, et al. Vitamin D receptor genetic polymorphism is significantly associated with risk of type 2 diabetes mellitus in Chinese Han population. Arch Med Res. 2015;46(7):572-579.

26. Khodaeian M, Enayati S, Tabatabaei-Malazy O, Amoli MM. Association between genetic variants and diabetes mellitus in Iranian populations: a systematic review of observational studies. J Diabetes Res. 2015;2015:585917.

27. Fitzpatrick TB. The validity and praticality of sun-reactive skin types $i$ through VI. Arch Dermatol. 1988;124(6):869-871.

28. Ersfeld DL, Rao DS, Body JJ, et al. Analytical and clinical validation of the $25 \mathrm{OH}$ vitamin D assay for the LIASON automated analyzer. Clin Biochem. 2004;37(10):867-874.

29. Gentil P, de Lima Lins TC, Lima RM, et al. Vitamin-d-receptor genotypes and bone-mineral density in postmenopausal women: interaction with physical activity. J Aging Phys Act. 2009;17(1):31-45.
30. Wang Q, Xi B, Reilly KH, Liu M, Fu M. Quantitative assessment of the associations between four polymorphisms (FokI, ApaI, BsmI, TaqI) of vitamin D receptor gene and risk of diabetes mellitus. Mol Biol Rep. 2012;39(10):9405-9414.

31. Li L, Wu B, Liu JY, Yang LB. Vitamin D receptor gene polymorphisms and type 2 diabetes: a meta-analysis. Arch Med Res. 2013;44(3):235-241.

32. Abu el Maaty MA, Hassanein SI, Sleem HM, Gad MZ. Vitamin D receptor gene polymorphisms (TaqI and ApaI) in relation to 25-hydroxyvitamin D levels and coronary artery disease incidence. J Recept Signal Transduct Res. 2014;1-5.

33. Pilz S, Tomaschitz A, März W, et al. Vitamin D, cardiovascular disease and mortality. Clin Endocrinol (Oxf). 2011;75(5):575-584.

34. Anderson JL, May HT, Horne BD, et al. Relation of vitamin D deficiency to cardiovascular risk factors, disease status, and incident events in a general healthcare population. Am J Cardiol. 2010;106(7):963-968.

35. Zehnder D, Bland R, Chana RS, et al. Synthesis of 1,25 dihydroxyvitamin $\mathrm{D}(3)$ by human endothelial cells is regulated by inflammatory cytokines: a novel autocrine determinant of vascular cell adhesion. J Am Soc Nephrol. 2002;13:621-629.

36. Aihara K, Azuma H, Akaike M, et al. Disruption of nuclear vitamin D receptor gene causes enhanced thrombogenicity in mice. $J$ Biol Chem. 2004;279:35798-802.

37. Zittermann A, Schleithoff SS, Koerfer R. Putting cardiovascular disease and vitamin $\mathrm{D}$ insufficiency into perspective. $\mathrm{Br} J$ Nutr. 2005;94(4):483-492.

38. Li YC, Kong J, Wei M, Chen ZF, Liu SQ, Cao LP. 1,25-Dihydroxyvitamin $\mathrm{D}(3)$ is a negative endocrine regulator of the renin-angiotensin system. J Clin Invest. 2002;110(2):229-238.

39. Tomaschitz A, Pilz S, Ritz E, et al. Independent association between 1,25-dihydroxyvitamin $\mathrm{D}, 25$-hydroxyvitamin $\mathrm{D}$ and the renin-angiotensin system: the Ludwigshafen Risk and Cardiovascular Health (LURIC) Study. Clin Chim Acta. 2010;411(17-18):13541360.

40. Vaidya A, Forman JP, Hopkins PN, Seely EW, Williams JS. 25-hydroxyvitamin $\mathrm{D}$ is associated with plasma renin activity and the pressor response to dietary sodium intake in Caucasians. $J$ Renin Angiotensin Aldosterone Syst. 2011;12(3):311-319.

41. Pan XM, Li DR, Yang L, et al. No association between vitamin D receptor polymorphisms and coronary artery disease in a Chinese population. DNA Cell Biol. 2009;28(10):521-525.

42. Laczmanski L, Milewicz A, Lwow F, et al. Vitamin D receptor gene polymorphism and cardiovascular risk variables in elderly Polish subjects. Gynecol Endocrinol. 2013;29(3):268-272.

43. Vaidya A, Sun B, Forman JP, et al. The Fok1 vitamin D receptor gene polymorphism is associated with plasma renin activity in Caucasians. Clin Endocrinol (Oxf). 2011;74(6):783-790.
The Application of Clinical Genetics

\section{Publish your work in this journal}

The Application of Clinical Genetics is an international, peer-reviewed open access journal that welcomes laboratory and clinical findings in the field of human genetics. Specific topics include: Population genetics; Functional genetics; Natural history of genetic disease; Management of genetic disease; Mechanisms of genetic disease; Counselling and ethical

\section{Dovepress}

issues; Animal models; Pharmacogenetics; Prenatal diagnosis; Dysmorphology. The manuscript management system is completely online and includes a very quick and fair peer-review system, which is all easy to use. Visit http://www.dovepress.com/testimonials.php to read real quotes from published authors. 